\title{
IGFBP5 Gene
}

National Cancer Institute

\section{Source}

National Cancer Institute. IGFBP5 Gene. NCI Thesaurus. Code C24490.

This gene plays a role in the intracellular transport of insulin-like growth factor moieties. 